\title{
Resistance and compliance in women's academic identity work in the Global South
}

\section{Ikhwan Maulana Haeruddin ${ }^{1}$ (D) | David Pick ${ }^{2}$ | Htwe Htwe Thein ${ }^{2}$}

\author{
${ }^{1}$ Department of Management, Universitas \\ Negeri Makassar, Makassar, Indonesia \\ ${ }^{2}$ School of Management, Curtin University, \\ Perth, Western Australia, Australia \\ Funding information \\ Direktorat Jenderal Pendidikan Tinggi, \\ Grant/Award Number: 210/E4.4/K/2012
}

\begin{abstract}
The aim of this study is to explore women academic's identity work in the context of the Global South (Indonesia). This is done by examining how the interplay between macrolevel social, cultural and political influences and micro-processes produce moments of compliance and resistance. To this end, the following research question is posed: What is the nature of identity work among women academics in higher education institutions of the Global South where there are shifting and conflicting social and cultural conditions? This study contributes by illuminating the ways in which women comply with or resist traditional and contemporary organisational and occupational structures that produce gender inequality. It also contributes to understanding how the interplay of power and resistance influences women's academic identity work in developing nations.
\end{abstract}

\section{1 | INTRODUCTION}

Higher Education in Indonesia is going through a transformation that mirrors global trends. These changes are creating an environment in which there is an increasing prevalence of identity breakdown and fragmentation (Harris, 2005) to the extent that academic identities are in a constant state of construction, destruction and reconstruction (Billot, 2010). This is symptomatic of a work environment where there are multiple, expanding and conflicting ideas about what it is to be an academic (Guzmán-Valenzuela \& Barnett, 2013) where academics are required to be able to cope with various threats to their academic identities (Clegg, 2008) and because 'becoming an academic is a complex process in which the subject acts in order to get recognition' (Angervall, 2018, p. 108). This is problematic as they are not only upholding their personal-internal identities to maintain a sense of coherence and authenticity, but also managing their public (academic-professional) identity in order to deal with 
monolithic organisational stories of neoliberalism and global competition (Churchman \& King, 2009). This often leads to academics finding it difficult to establish who they are (Barnett, 2000).

As in many other parts of the world, women working in Indonesian Higher Education are facing complex and contradictory challenges to the way in which they develop their academic identity arising from competing demands and work situations where organisational cultures tend to favour masculine values (Fotaki, 2013). In such work settings women are often expected to be responsive to child-rearing and housework, while at the same time dealing with pressures to perform in their current role at work as well as trying to climb the career ladder (Angervall, 2018; Harris, Myers, \& Ravenswood, 2017; Howe-Walsh \& Turnbull, 2016; Jacobs \& Winslow, 2004; Nikunen, 2012; Ylijoki, 2011). This is significant because identity work is 'more necessary, frequent and intense in situations where strains, tensions and surprises are prevalent, as these prompt feelings of confusion, contradiction and self-doubt, which in turn tend to lead to self-examination' (Brown, 2015, p. 6). Moreover, scholars argue that identity work is often performed in challenging circumstances or at times of significant transition and liminality (Aschraft, 2012; Petriglieri, 2011), within socially formed discourses (Alvesson \& Willmott, 2002; Clarke, Brown, \& Hope-Hailey, 2009), demanding professional careers (Kreiner, Hollensbe, \& Sheep, 2006), and during times of culture and values change (Kosmala \& Herrbach, 2006). Given the context of this research and the yet-to-be resolved theoretical and practice-world problems identified in the identity work literature, this research contributes by providing new insights that will not only progress theoretical understandings of identity work but also provide perspectives from the Global South that could assist with eliminating gendered organisational cultures, attitudes and work practices that are associated with the under-representation of women in senior organisational positions, particularly in academia. By examining the evolving work identities in aspiring and established women academics in Indonesian universities, the widely held assumption that Indonesian women (like in other nations of the Global South) often succumb to socio-cultural pressures to conform to work identities that are prescribed by religious teaching is challenged (Jaschok \& Shui, 2013; Melman, 2016).

In sum, there is a need to understand better the ways that women resist and reform organisational and occupational structures, how gender inequality is reproduced or challenged, and the extent to which the situation in the Global South is different from developed nations (Muzio \& Tomlinson, 2012). This is particularly important when the ways in which power and resistance influence women's identity work trajectories are illuminated (JärventieThesleff \& Tienari, 2016).

As a developing nation, Indonesia provides opportunities for studying identity work among women in the Higher Education work setting in ways that will uncover new theoretical insights that are applicable to a diversity of contexts globally. As well as being the fifth largest nations in the world by population, Indonesia is a young and thriving multicultural, multi-party democracy where tradition, religion, modernity and postmodernity are thrust together in a rapidly evolving political, economic, social and cultural context. This has created a situation where tensions between traditional values and identities, contemporary masculine values and women's career aspirations are writ large. Similar to many other nations, the Higher Education environment in Indonesia as elsewhere exemplifies the ways in which Indonesian women are confronted with trying to reconcile their career identity and aspirations with demands arising from responsibility at work, and with expectations stemming from traditional views about the roles they must take-on in the domestic sphere (Lindawati \& Smark, 2015).

The main aim of this paper is to seek answers to and possible resolutions to these problems by examining academic identity work processes of women in Indonesian public universities. To this end, the following question is examined: What is the nature of identity work among women in higher education institutions of the Global South where there are shifting and conflicting social, cultural and political conditions? Seeking answers to this question is important because understanding how women deploy their identity work resources in the academic arena provides insights into how these resources not only allow women to navigate competing demands on them, but also how they can be agents of change that will improve women's academic work and career conditions in universities around the world. 
Global South such as Indonesia. Future investigations are needed to answer remaining questions about whether new and alternative identity work processes can successfully challenge and change dominant influences that limit the career and life aspirations of women.

\section{ORCID}

M. Ikhwan Maulana Haeruddin (D) https://orcid.org/0000-0003-2704-1876

\section{REFERENCES}

Altbach, P. G. (2010). The Asian higher education century? The future of Asia. The Boston College Center for International Higher Education, 59, 3-5.

Alvesson, M., \& Billing, Y. D. (2009). Understanding gender and organizations. London, United Kingdom: Sage.

Alvesson, M., \& Willmott, H. (2002). Identity regulation as organizational control: Producing the appropriate individual. Journal of Management Studies, 39, 619-644. https://doi.org/10.1111/1467-6486.00305

Angervall, P. (2018). The academic career: A study of subjectivity, gender and movement among women university lecturers. Gender and Education, 30, 105-118. https://doi.org/10.1080/09540253.2016.1184234

Archer, L. (2008). Younger academics' constructions of "authenticity", "success" and professional identity. Studies in Higher Education, 33, 385-403. https://doi.org/10.1080/03075070802211729

Ashcraft, K. (2012). The Glass Slipper: "Incorporating" Occupational Identity in Management Studies. Academy of Management Review, 38(1), 6-31.

Barnett, R. (2000). Realizing the university in an age of supercomplexity. Buckingham, United Kingdom: SHRE and Open University Press.

Beech, N., Gilmore, C., Hibbert, P., \& Ybema, S. (2016). Identity-in-the-work and musicians' struggles: The production of selfquestioning identity work. Work, Employment and Society, 30, 506-522. https://doi.org/10.1177/0950017015620767

Billot, J. (2010). The Imagined and the real: Identifying the tensions for academic identity. Higher Education Research and Development, 29, 709-721. https://doi.org/10.1080/07294360.2010.487201

Blackburn, S., Smith, B. J., \& Syamsiyatun, S. (2008). Indonesian Islam in a new era: How women negotiate their Muslim identities. Melbourne, Australia: Monash University Press.

Brown, A. D. (2015). Identities and identity work in organizations. International Journal of Management Reviews, 17, 20-40. https://doi.org/10.1111/ijmr.12035

Brown, A. D., \& Humphreys, M. (2006). Organizational identity and place: A discursive exploration of hegemony and resistance. Journal of Management Studies, 43, 231-257. https://doi.org/10.1111/j.1467-6486.2006.00589.x

Buchanan, F. R., Warning, R. L., \& Tett, R. P. (2012). Trouble at the top: Women who don't want to work for a female boss. The Journal of Business Diversity, 12, 33.

Buchori, M., \& Malik, A. (2004). Higher education in Indonesia. In P. Altbach \& T. Umakoshi (Eds.), Asian universities: Historical perspectives and contemporary challenges (pp. 249-278). Baltimore, MD: Johns Hopkins Press.

Carrim, N. M. H., \& Nkomo, S. M. (2016). Wedding intersectionality theory and identity work in organizations: South African Indian women negotiating managerial identity. Gender, Work and Organization, 23, 261-277.

Chasserio, S., Pailot, P., \& Poroli, C. (2014). When entrepreneurial identity meets multiple social identities: Interplays and identity work of women entrepreneurs. International Journal of Entrepreneurial Behavior and Research, 20, 128-154. https://doi.org/10.1108/IJEBR-11-2011-0157

Churchman, C., \& King, S. (2009). Academic practice in transition: Hidden stories of academic identities. Teaching in Higher Education, 14, 507-516. https://doi.org/10.1080/13562510903186675

Clarke, C. A., Brown, A. D., \& Hope-Hailey, V. (2009). Working identities? Antagonistic discursive resources and managerial identity. Human Relations, 62, 323-354. https://doi.org/10.1177/0018726708101040

Clarke, L. (2014). Can Indonesia fulfil its scientific potential? [Online] Retrieved from http://blogs.royalsociety.org/ in-verba/2014/09/11/can-indonesia-fulfil-its-scientific-potential/

Clegg, S. (2008). Academic identities under threat? British Educational Research Journal, 34, 329-345.

Constantine, M. G., Miville, M. L., Warren, A. K., Gainor, K. A., \& Lewis-Coles, M. A. E. (2006). Religion, spirituality, and career development in African American college students: A qualitative inquiry. The Career Development Quarterly, 54, 227-241. https://doi.org/10.1002/j.2161-0045.2006.tb00154.x

Creswell, J. W. (2013). Qualitative inquiry and research design: Choosing Among five approaches (3rd ed.). Los Angeles, CA: Sage Publications.

DIKTI (Direktorat Jenderal Pendidikan Tinggi - Directorate General of Higher Education). (2014). Pedoman Operasional Penilaian Angka Kredit Kenaikan Pangkat/Jabatan Akademik Dosen [Operational Guidance of Credit Points on Rank Promotion/ Academic Position] Retrieved from http://pak.dikti.go.id/portal/?file_id=18 